\title{
Export Scenario Between Bangladesh and China: Opportunities of Bangladesh in RMG Sector
}

\author{
Professor Dr. Engr. Ayub Nabi Khan \\ Pro-vice Chancellor - BGMEA University of Fashion \& Technology \\ Md. Rashed Ullah \\ Technical \& Social Compliance Auditor - ITS Labtest Bangladesh Ltd.
}

Doi: 10.19044/esj.2017.v13n28p299 URL:http://dx.doi.org/10.19044/esj.2017.v13n28p299

\begin{abstract}
The Ready-made Garment (RMG) industry has already promoted itself as the largest foreign currency earning sector for Bangladesh and occupying the $2^{\text {nd }}$ position in leading exporters of clothing. From a humble beginning in late 70's RMG sector has emerged itself and did employment about 4.5 million peoples. China is the largest clothing exporter and represents the lion's share of the world market. In spite of being the second largest exporter, Bangladesh is far behind from China in any category of this sector including export earnings and a number of markets. Whereas China occupies one-third of global market share, Bangladesh has only 6 percent share in clothing export in the world but acts as a lifeline in her economy having 82 percent contribution of export earnings. Bangladesh could be more successful in this sector if it utilizes the available opportunities. For this, Bangladesh should try to grab the opportunities impeding in front because of backwardness of China in clothing export originating recently due to the transformation of the economy to high technology production and higher labor cost in garments. Hence it is important for policy makers to find out the facts and figure in exports of Bangladesh RMG to China. This paper will exhibit the comparativeness of Bangladesh vis-à-vis China in Ready-made Garment sector. Statistical analysis and secondary data sources have been used to make a broad discussion for this study. Bangladesh has the potentialities to be the next China if it can perform well according to the demand and challenges.
\end{abstract}

Keywords: RMG, Bangladesh, China, Export, Wage

\section{Introduction}

It is high time the Ready-made Garments (RMG) sector of Bangladesh started its prosperous journey with a great contribution to 
country's GDP and foreign exchange earnings which created a tremendous exemplary for many LDC's of the world. Currently, Bangladesh is the second largest RMG exporter of the world holding its continuity of exporting major apparel products to EU and USA. From a humble beginning with only 384 units in 1984-85, the sector has thus made phenomenal growth over the last two decades, the number of units growing to around 4500 (BGMEA, 2015). Since 1990 when the significant economic reform of Bangladesh started, it achieved a growth rate far superior to that of most low-income countries. In FY 2015-16 the GDP growth picked up around half percentage point to $7.11 \%$ from $6.55 \%$ in FY 2014-15. Growth was underpinned by the moderate growth in agriculture and robust performance in industry, aided by a buoyant service sectors (Bangladesh Economic Review, 2016). Bangladesh government now seeks to raise investment to $32 \%$ of the country's GDP within two years in pursuit of an $8.0 \%$ growth in the gross domestic product (The Financial Express, 18 Jan 2017). Previously the major export income was contributed by jute sector, but the scenario become changed. From 1995, total RMG exports increased from 2.5 billion USD to 28.7 billion USD in 2016 representing a contribution of about 82 percent of the country's total export earnings. The expansion of employment in Bangladesh RMG sector underwent a robust growth since the commencement of this industry. About 4.2 million workers are directly involved with the RMG sector (BKMEA, 2015).

China has been producing labour-intensive products and selling them to the rest of the world since the 1970's and achieved an increase. Since the introduction of the economic reforms in 1978, China has become the world's manufacturing hub, where the secondary sector (comprising industry and construction) represented the largest share of GDP. With a population of 1.3 billion and rapid economic growth, China dominates the world potentially as the largest exporter of clothing and textiles. Textile and Apparel exports accounted for $12 \%$ of overall merchandise export market in China in 2015. Main export categories include machinery and electronic products $(42.23 \%)$, miscellaneous $(10.50 \%)$, metals $(7.75 \%)$, stone and glass $(3.0 \%)$, (World Integrated Trade Solution, 2015). Since the WTO Agreement on Textiles and Clothing (ATC), which replaced the Multi-Fibre Arrangement (MFA), China has accelerated its integration into global production networks (GPNs). According to CNGA (China National Garment Association), there are more than 100,000 garment manufacturers with decent capacity in China which employ over 10 million people. Through a continuous path of technical innovation, China gained decades of experience in production management. China has the advantageous capacity in making all kinds of garment products in a fast and timely manner, which secures its front ranking in the world market in terms of capacity and quality. The total export value of China's 
apparel products in 2015 was 174.7 billion US dollars, a decrease of $-6.38 \%$ over last year accounting for $7.68 \%$ of China's total export income. In Textile export, China also remained top although experienced a decline in the value than the previous year. The value recorded 109 billion USD with 2\% decline in annual percentage (World Trade Statistical Review, 2016). Bangladesh remained second largest exporter positioned next to China with $7.76 \%$ annual percentage change and USD 28.7 billion export value in 2016 (BGMEA,2016).

\section{Background of the study}

China's garment export industry experienced a severe decline in sales in both 2015 and 2016. China's apparel export to the European Union (28) reached 41.2 billion USD, falling by $10.2 \%$ year-on-year, the export to Japan reached 17.3 billion USD, dropping 12.2\%, and the export to ASEAN countries hit 35.5 billion USD, slipping $8.5 \%$ in 2015 according to UNCTAD statistics data center. ${ }^{4}$ The sharply depreciated yen and Euro in 2015 had a direct negative impact on textile exports, as Japan and Europe have been China's main textile export markets. As China is undergoing an economic transformation, high-technology industries are springing up in China's developed coastal regions to replace labor-intensive industries such as the textile industry. As forecasted earlier by World Bank, China's exports of labor-intensive manufactured goods declined recently. Hussain (2013) mentioned that Bangladesh could become the alternative to China by taking the advantage of markets China is vacating. Bangladesh can take the advantage of a low-cost edge over its competitors. The minimum monthly wage in Bangladesh is \$68, while it is \$128 in Cambodia, \$78 in India, \$100 in Vietnam and $\$ 165$ in China (ILO, 2015). The report also added that capturing just $1 \%$ of China's manufacturing export markets would almost double Bangladesh's manufactured exports.

The worldwide clothing and textile business are going through a shift. It is now more modernized, more dimensional, and more vibrant. Also, the global value chain for clothing trade integrates more rapidly than ever before. After passing decades of tremendous success \& outstanding growth, RMG sector has emerged itself as a potential sector in Bangladesh's economy. Nevertheless, the gap between Bangladesh and China is huge regarding the volume of the market share by these two countries. Significantly, being the 2nd largest exporter of apparel, Bangladesh occupies only 5.9 percent of the total share of the market whereas China has 39.3

\footnotetext{
${ }^{4}$ Source: UNCTAD data center: Product group [84] represents apparel products. Available at: UNCTAD statistics data center> International trade in goods and services $>$ trade structure by partner, product or service-category> Merchandise trade matrix-Product groups, Exports.
} 
percent share with its large capacity in an offer (World Trade Statistical Review, 2016). One can easily deduce the supremacy of China undoubtedly, and its domination will not diminish soon. But recently the competition to capture the export share of world apparel market has increased more than the past as backpedaling of China on apparel export has created a vacuum in the trade and the competitor countries of Bangladesh are striving their best to craft out their positions in the international markets. To compete with the world's largest exporter of RMG, Bangladesh needs to find out the gaps, comparativeness, new commodious markets and most importantly Bangladesh should be more conscious and uncompromising about the quality of the product. At the same time, Bangladesh will have to ensure proper utilization of the prospects, once any opportunity comes to grab the share of the potential market left by China. However, competition from the apparel exporters for global garment buyers is motivated by not only expanding export market share and economic growth but also the potential to create jobs. The key is to ensure that the dynamism in the industry leads to new jobs for women and men as well as better quality jobs with decent working conditions and adequate wages.

\section{Objectives}

This paper is presented with comparative analysis and discussion has been made to determine some important aspects of Bangladesh Ready-made garments sector. The purpose of this study aims to find the prospects \& challenges of Bangladesh RMG sector through a presentation of the comparison of China \& Bangladesh. This paper examines the trends (of RMG sector) between Bangladesh and China. The analytical scenario will focus China's recent step backwardness in RMG sector which opens the door for emerging clothing exporters like Bangladesh. The upcoming opportunities for Bangladesh is discussed in Ready-made garments industry. This paper will present facts and figures which will help analysts, researchers of related field, etc. for gathering knowledge regarding the scenario of Bangladesh Ready-made garments sector.

\section{Methodology}

This study is focused to statistics analysis and literature review. Data and information from secondary sources were collected from various relevant trade statistics websites, studies conducted by various journals and research articles and working papers. Information over the last twenty years from 1995 to 2015 has been gathered to analyze the growth of market and development on clothing export earnings as Market Diversification entails both Market as well as Product Developments. 
To present the condition and opportunities of Bangladesh, information published in the different newspapers and websites have been studied and analyzed. The collected data and information are analyzed and processed to reveal the findings and gaps between them.

\section{Literature review}

One reason of decline in China's RMG export in recent years is that the economy is moving faster towards high-technology production. The wages of Chinese garment workers have been doubled, resulting in higher costs of production. The Chinese labor force has stepped up on productivity and skill level to compete in other industries. Garment manufacturing is a low-skilled, labor-intensive industry, which is no longer with the wheel as per statistics of recent years.

Rahman and Siddiqui (2015) presented several crucial factors like gradual reduction in China's bulk production due to labor shortages and higher wages that have been playing an important role in facilitating the growth of the sector. In the report known as McKinsey Report, Berg et al. (2011) found that the potency for the emerging garment industry is becoming more prospectus. Consulting with the Chief Purchasing Officers (CPO $)^{5}$ of leading apparel companies in Europe and the US (who cover the 66 percent apparel export of Bangladesh to Europe and US), the report opined that buyers see Bangladesh as the next destination for major apparel sourcing after China. Due to the increased labor cost and capacity constraints in China and other markets, the declining profit margin is the key issue to divert buyer's preferred attention to Bangladesh. Yunus and Yamagata (2012) expressed that the potential for Bangladesh to assert its cheap labor based competitive advantage circumscribed by the low-cost share of labor in RMG products. "Many labor-intensive Chinese industries had already shifted to Southeast Asian countries," said Zhang Jianping, a senior researcher at the Institute for International Economic Research under the National Development and Reform Commission. "The labor costs there are four to five times cheaper than in China." (China Daily, 14 Jan 2016)

Martin (2009) stated that the export barriers under Multi Fibre Agreement were a particularly big problem for countries such as China that had quotas despite having productive potential. Mallon and Whalley (2004) presented in a survey after accession to WTO that China also faced many critical challenges in the area of anti-dumping. Around $15 \%$ of antidumping actions occurred against China since she was a dynamic model of exports.

\footnotetext{
${ }^{5}$ McKinsey survey was conducted by consulting with Chief Purchasing Officers (CPO) of US and Europe who accounts for 46 billion in total apparel sourcing value and covering 66 percent of all apparel exports from Bangladesh to US and Europe. An extensive interviewbased survey was taken with CPO's for the purpose of survey.
} 
Hasan (2013) pointed out two factors such as cheap labor force and captive market under the quota system that facilitated the development of RMG industry in Bangladesh. A report of World Bank focused some prerequisites to improve e.g. productivity, product quality and lead times to win the competitive race with China and other emerging exporters so that Bangladesh could position itself as an indomitable supplier of clothing (World Bank, 2005). Nuruzzaman and Haque (2009) found that the current RMG manufacturers of Bangladesh are importing most of the required woven fabrics from China, India, Pakistan, and Indonesia. As a result, the total lead time is becoming longer, putting a negative edge on competitiveness. Asgari and Hoque (2013) suggested that domestic supply of fabrics can mitigate the cost of production. Adnan et al. (2015) identified that the net value addition of RMG export is not very lucrative because of the weak backward linkage and high amount import of raw materials. Zhang et al. described that the first challenge of China's clothing industry is the lack of technology equipment for which procrastination occurs to develop the products. Hence, long product development cycle is faced by the producers. Another problem was stated by Xiang and Zhenzhen (2010) that few factories emphasis on the priority of style, not the quality of garments. They are also reluctant to protect the environment. Hossen (2014) recommended that there should be research and training institute to develop the RMG export. Expansion of export development fund with simplification of export procedures can accelerate the onward role of Bangladesh in competition with China and other exporters.

China's garment industry is concentrated in the coastal areas of the country. According to Fair Wear Foundation report, the top five regions of China's garment production in terms of export value are Zhejiang (32.06 billion value, $11.68 \%$ growth rate), Jiangsu (24.79 billion value, $4.46 \%$ growth rate), Guangdong (33.31 billion value, $5.51 \%$ growth rate), Fujian (16.88 billion value, $19.26 \%$ growth rate), and Shandong Provinces (11.4 billion value, $7.47 \%$ growth rate). Uddin (2014) revealed the fact that any political violence, strike in Bangladesh interrupts the whole garment transportation system through the shipment because of the centralization of this industry near Dhaka. Qiu (2005) found that, with the improving living standard of the Chinese people, local demand for high-quality textile and apparel goods continued to rise which brought another wave for changes in the industry of China.

\section{Results and Discussion \\ Annual GDP and growth (\%)}

The Chinese economy experienced an astounding growth in the last few decades that actuated the country to become the second largest economy 
of the world. China's annual Gross Domestic Product (GDP) achieved a robust prosperity enriching from USD 2.75 trillion in 2006 to USD 11 trillion in 2015, with a 6.9 percent annual growth rate (Figure 1). In 2014, annual GDP was USD 10.48 trillion with a much higher growth rate of 7.3 percent. In 2015, GDP per capita recorded USD 8027.68 which was USD 7683.50 in 2014.

Figure 1: Annual Gross Domestic Product and growth \% of Bangladesh and China

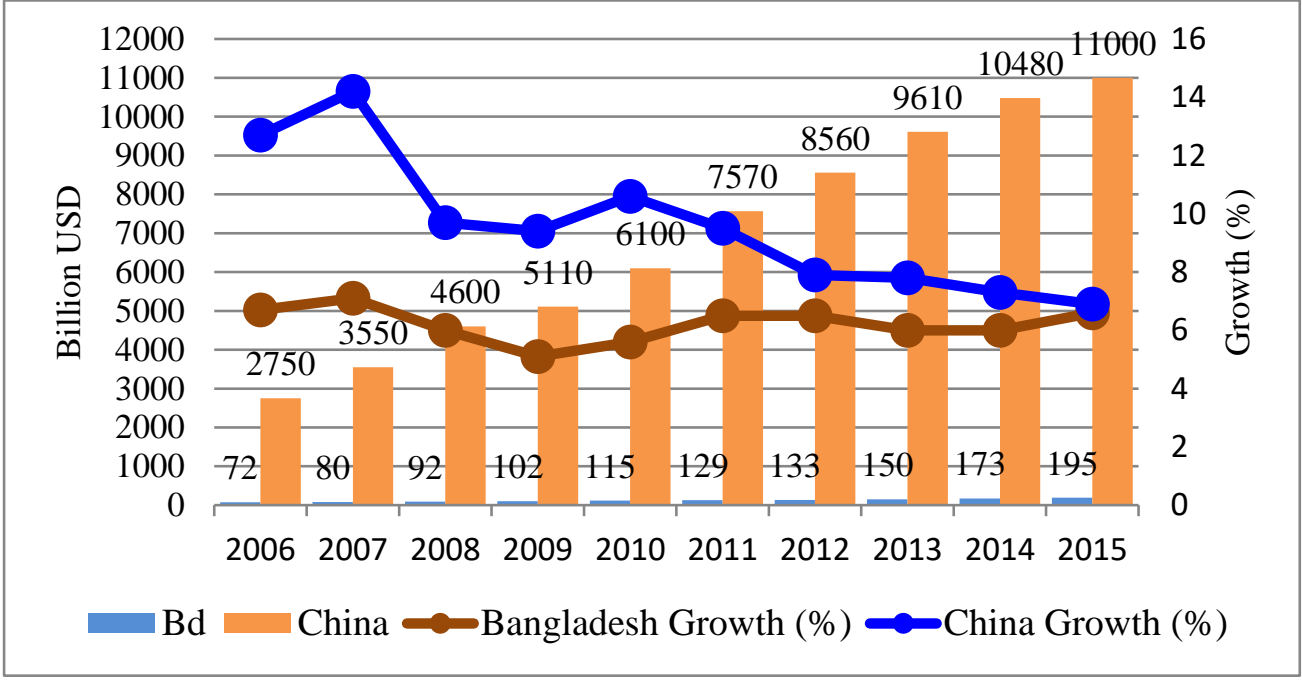

Source: World Bank (2006-2015)

In the last decade, Bangladesh has recorded GDP growth rates above 5 percent influenced by massive development in the garment industry. Although three-fifths of Bangladeshis employed in the agriculture sector, three-quarters of exports revenues come from producing Ready-made garments. Bangladesh's economy grew by 6.5 percent in 2011, remained stable in 2012 and slowed down to 6.0 percent in 2013. In 2014 GDP growth was stable too and in 2015, GDP grew by 6.6 percent (Figure 1). Per capita GDP reached USD 1211.70 in 2015 . GDP per capita increased to a greater extent where it was only USD 495.85 in 2006.

\section{Annual trade balance (2000-2015)}

China's current account has recorded a surplus in every year since 1994. China reported USD 592998 million trade surplus in 2015, compared to a USD 383060 million surplus a year earlier. It was a surplus of USD 24179 million in 2000. As imports fell and exports rose, the trade balance of China followed a thriving path between the years 2003 to 2008 . Followed by the global recession, country's export earning became less in 2009. On the other hand, the volume of imports increased significantly in the subsequent years until 2013. The trade surplus of China reached USD 181507 million in 
2010 to USD 259015 million in 2013 as a fast growing economy with affluent high-technology industry. (Figure 2-A)

Figure: 2-A

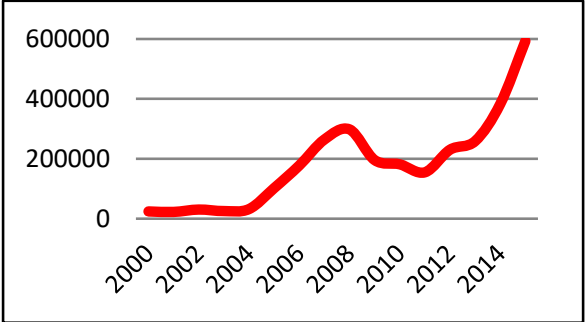

Figure: 2-B

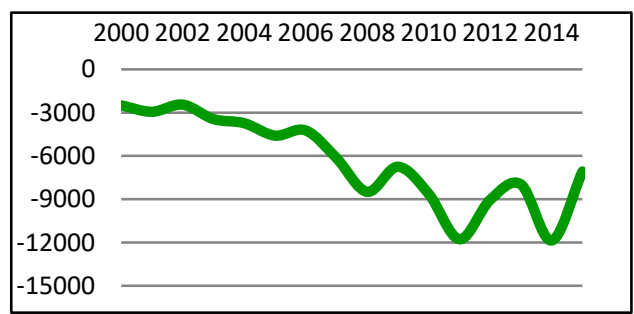

Source: UNCTAD Statistics, Merchandise trade balance, Annual.

Bangladesh has been recording sustained trade deficits since 1976 mainly due to a high value of imports. Bangladesh recorded a trade deficit of USD -7082 million in 2015. Balance of Trade of Bangladesh averaged USD -6351.31 million from 2000 until 2015, reaching the highest deficit of USD 11862 million in 2014 and the lowest of USD -2443 million in 2002 (Figure 2-B).

\section{Share in World's total clothing export}

China continued to play the most vital role being the lead exporter of clothing in last decade. From figure her dominance over the all exporters is visible too. China's annual share in world clothing market was 30.6 percent in 2006 and it reached to 39.3 percent in 2015 (Figure 3). The share was 38.6 percent in 2013 and 2014 consecutively and despite the declining export value in 2015, its share increased in the world clothing export.

Figure 3: Country's Share in World's clothing export

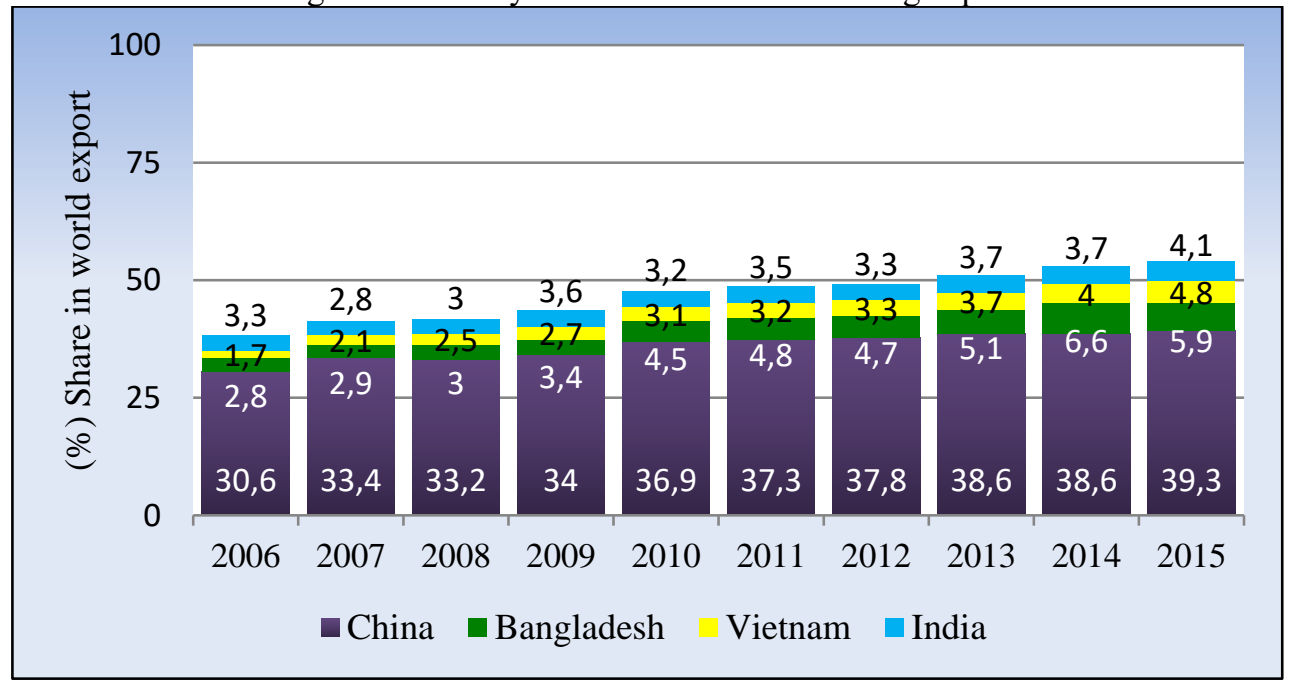

Source: International Trade Statistics (2006-2015) and World Trade Statistical Review 2016. 
The possession of Bangladesh as the 2nd largest exporter in 2015 recorded 5.9 percent which was 6.6 percent in the preceding year. The backwardness was invaded by sound advancement of her nearest competitors in apparel market, for instance, 4.8 percent share of Vietnam followed by 4.0 percent in 2014 and 4.1 percent share of India followed by 3.7 percent in 2014 (Figure 3). Though the annual value of export increased in 2015, this backwardness clearly indicates the hint of Bangladesh's high competitiveness with emerging clothing exporters in future.

\section{Annual total export value of clothing (1995-2015)}

In 2015, Bangladesh accounted for USD 26.6 billion (5.9 per cent) of global exports of garment. This marks an astounding rise from USD 2.5 billion in 1995. Figure 4 shows the continuous increase in export value of the country experienced no decline in annual export value for a particular year than the previous year after 2001. The value of RMG export increased USD 1083 million in 2014 than 2013 and USD 2019 million in 2015 than 2014.

Figure 4: Annual total export value of clothing

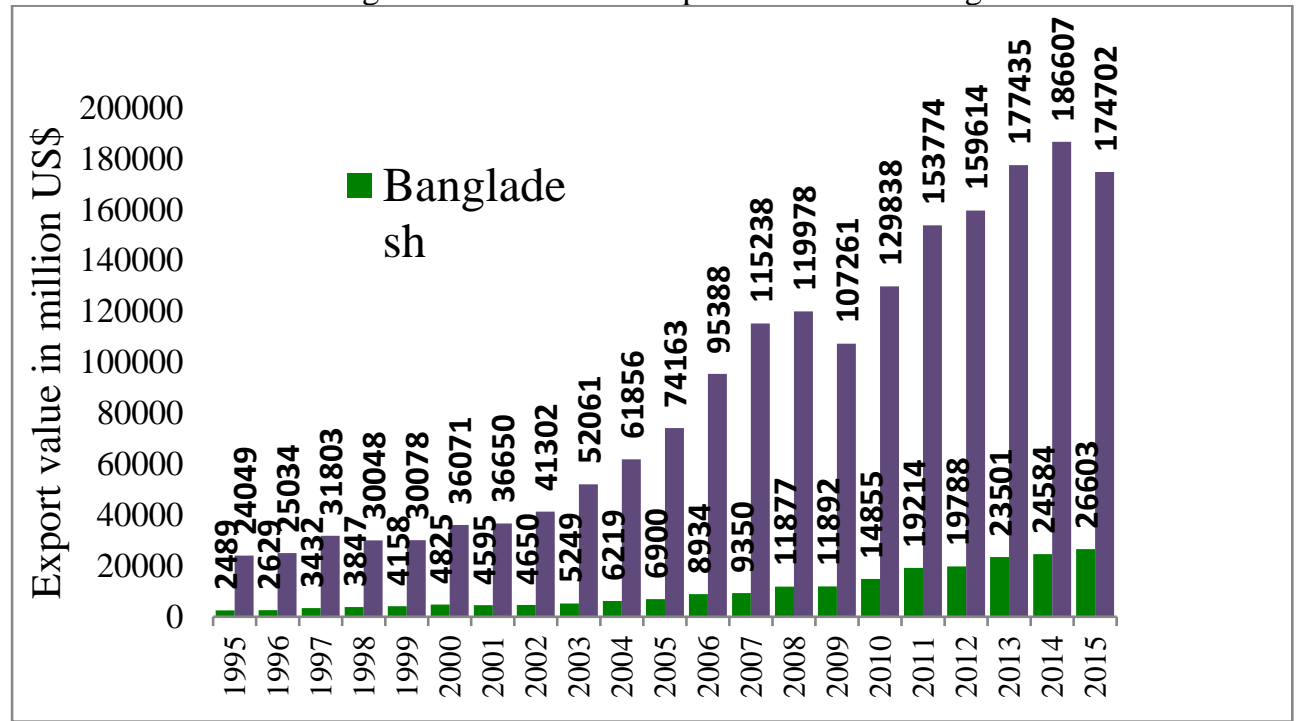

Source: International Trade Statistics and World Trade Statistical Review 2016, BGMEA trade database.

China has been the international leader in garment exports for decades. In 2015, it exported USD 174.7 (Figure 4) billion in apparel and dominated 39.3 percent of the export market share among all economies. Annual export growth from 1995 to 2015 was robust and exceeded doubledigits in Bangladesh (48.4 percent) and China (31.3 percent). Clearly, these trends provide strong indication that dominance of China in RMG is still exists. 


\section{Annual growth rate of Ready-made garments export}

Bangladesh's export grew by only 3 percent in 2012 whereas it grew by 29 percent in 2011. The export of Ready-made garments (RMG) was expected to be decreased in the subsequent years after massive accidents like collapse of 'Rana Plaza' and fire in 'Tazrin Fashions'. Those accidents created negative impressions on Bangladesh RMG. Nevertheless, Bangladesh achieved a healthy rate of growth in RMG export in the following years having 19 percent growth in 2013 and 5 percent growth in 2014 (Figure 5). This indicates the continuous improvement of the sector and the ability of overcoming sudden obstacles valiantly. However, growth becomes 8 percent in 2015 .

Figure 5: Annual growth rate of Ready-made garments export

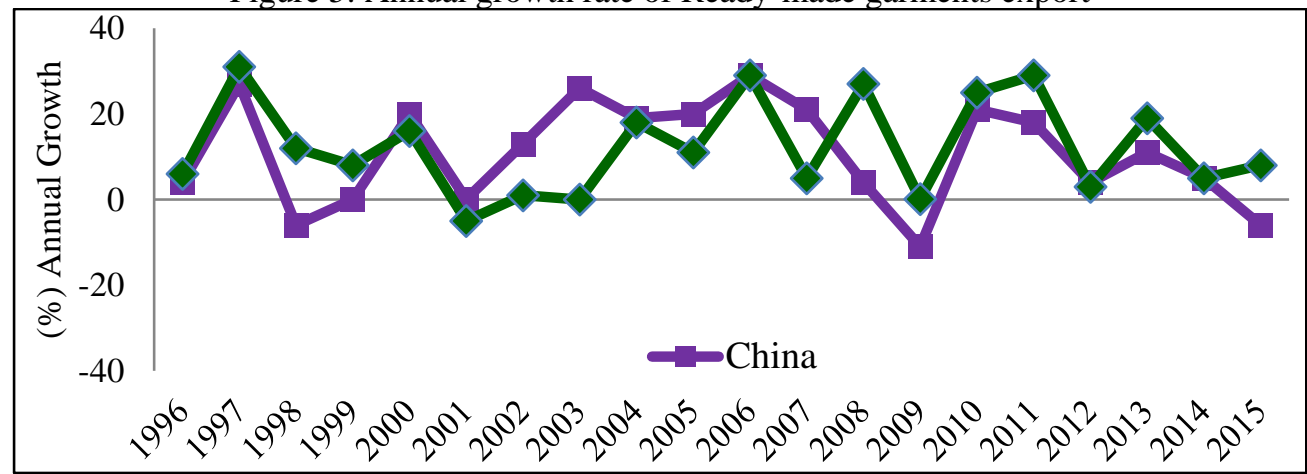

Source: International Trade Statistics and World Trade Statistical Review 2016, BGMEA trade database.

Annual growth in apparel exports from China recorded 5 percent in 2014, while the growth rate becomes down to -6 percent in 2015. Impacted by the financial crisis, clothing exports in China declined from USD 120.0 billion in 2008 to USD 107.2 billion in 2009, hitting the bottom at a negative growth rate of -11 percent (Figure 5), but bounced back to a positive 21 percent in 2010 to USD 129.9 billion. Particularly, the major contrast between Bangladesh and China in terms of annual growth rate is seen if the scenario is closely analyzed between recent years. Between 2010-2015 annual growth rates for China was only 6.96 percent where for Bangladesh, it was 15.82 percent.

\section{Share in economy's total merchandise exports}

Figure 6 shows how dominating contributor the RMG has become for Bangladesh throughout the years in the total merchandise exports of the country. In FY 2000, Bangladesh's Ready-made garments sector's contribution was 75.6 percent which in 2015 increased to 82 percent on its way to reach USD 28094.16 billion. Since its inception in early 80's (when 
the share was only 3.89 percent in FY 1983-84) this sector has established itself as a major source of export income for Bangladesh (BGMEA, 2015).

Figure 6: Share in economy's total merchandise exports

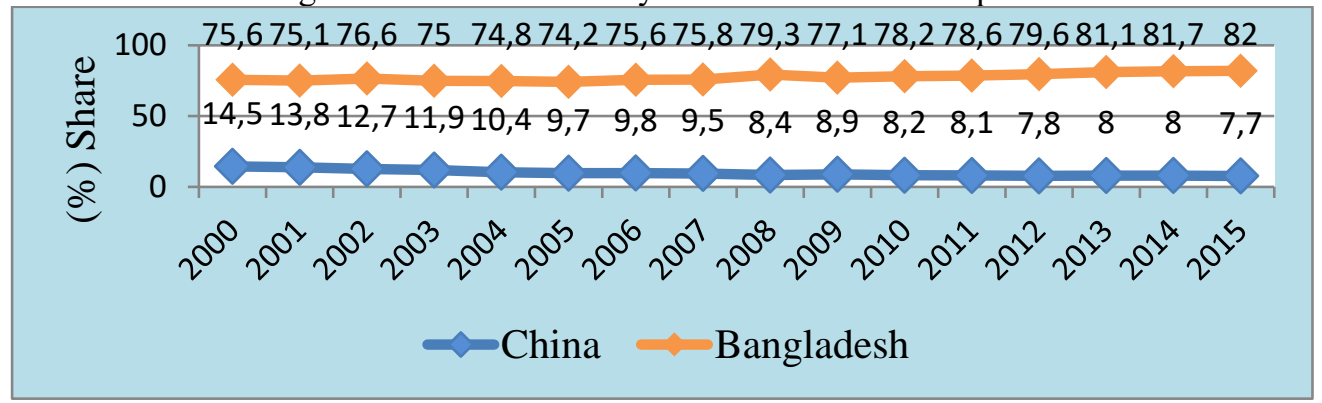

Source: International Trade Statistics and World Trade Statistical Review 2016, BGMEA trade database.

China's clothing export accounted for 7.7 percent to its total merchandise export in 2015 slowing from 8.0 percent a year ago. In 2000 China's clothing export contribution was 14.5 percent and it dropped down gradually mainly due to strong contribution of other manufacturing sectors in country's total merchandise export.

\section{RMG export earning VS Total export earning}

Figure 7-A: RMG export value VS Total export value (Bangladesh)

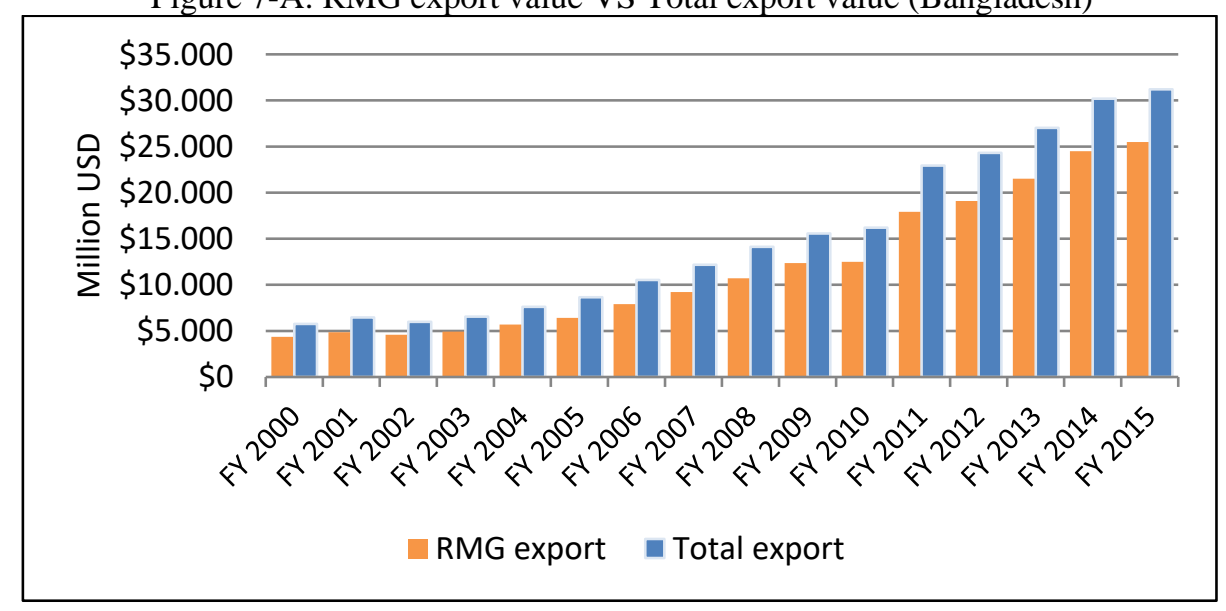

Source: BGMEA trade database.

Bangladesh's total export value in FY 2014-15 was USD 31.2 billion where it was USD 5.75 billion in FY 1999-2000 (Figure 7-A). In FY 200102 RMG sector had a poor export earnings (USD 4.58 billion) compared to previous Fiscal year (USD 4.86 billion) mainly due to the political instability regarding the national election of Bangladesh. In FY 2008-09 Bangladesh's total export earnings didn't fall only because of its RMG contribution to the 
economy which held a healthy growth in spite of the global recession. The importance of RMG sector in the country's economy can readily be clarified.

Figure 7-B: RMG export value VS Total export value (China)

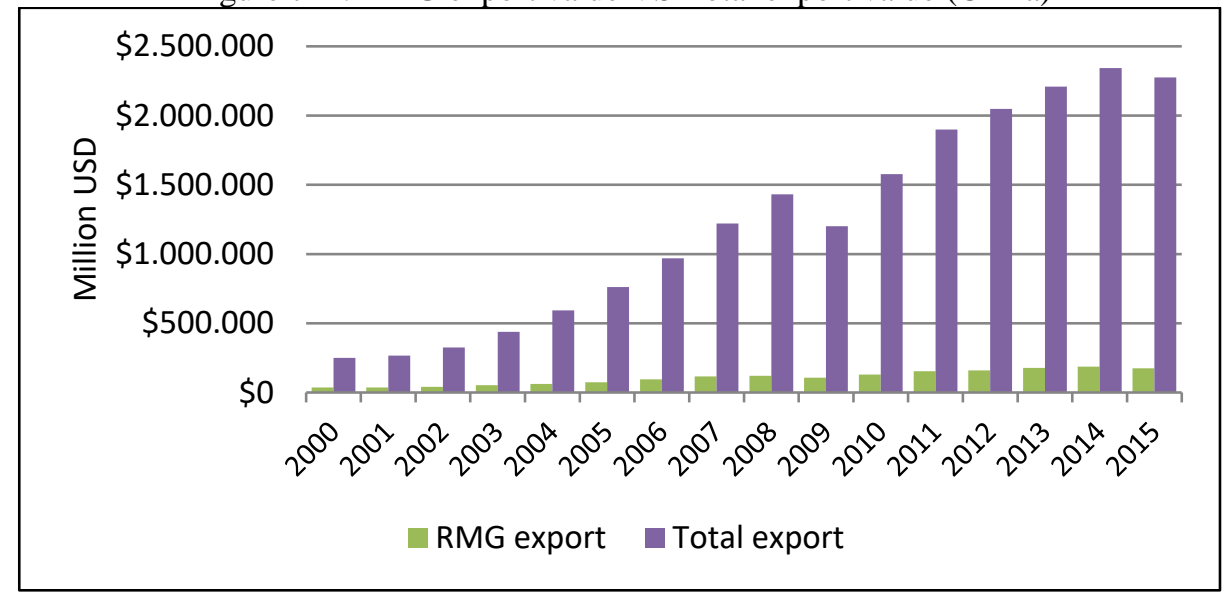

Source: UNCTAD Statistics data center.

In 2014 China exported USD 2.34 trillion, making it the largest exporter in the world (Figure 7-B). During the last five years the exports of China have increased from USD 1.58 Trillion in 2010 to USD 2.27 trillion in 2015. The major export earnings of China don't led by clothing sector like Bangladesh which represents only 7.7 percent of the total exports of China, accounted for USD 174.7 billion in 2015.

\section{Top 10 Ready-made garments (RMG) importers}

Figure 8-A: Top 10 Ready-made garments (RMG) importers of Bangladesh

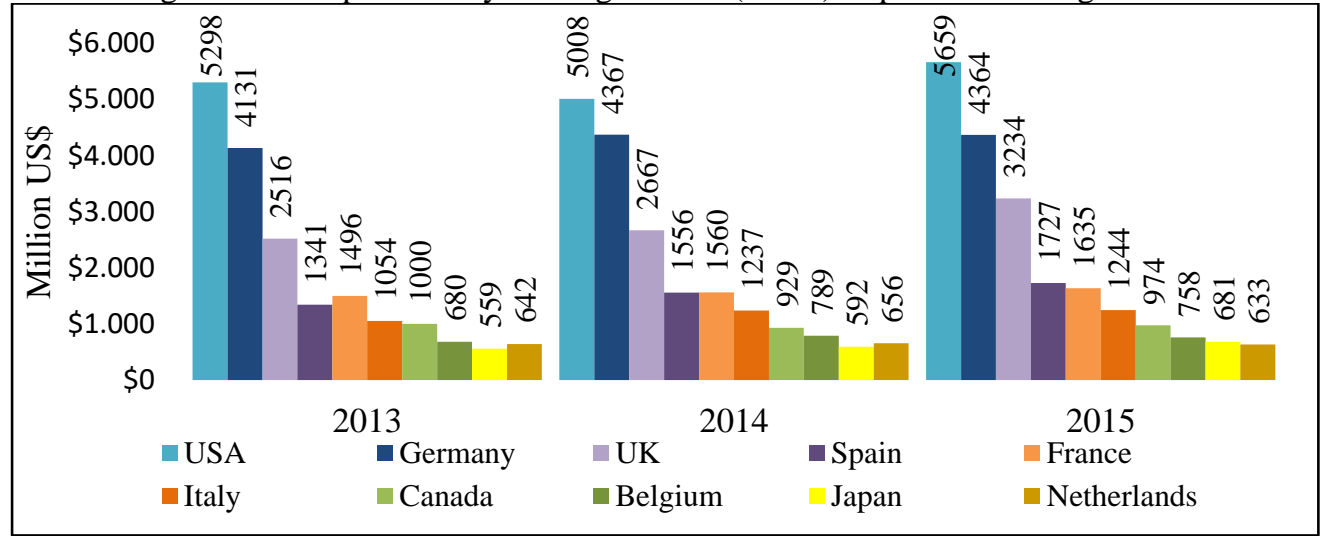

Source: BGMEA trade database.

The two major destinations for Bangladeshi garment exports have been the United States and the European Union which account for over 80 percent of the total exports. Figure 8-A provides information of 
Bangladesh's exports in top 10 destinations in recent years. USA is the most lucrative market for Bangladesh RMG Export. In 2013 the total export volume to USA was USD 5298 Million where it becomes USD 5008 million and USD 5659 million in 2014 \& 2015 respectively achieving 13 percent of growth in 2015. German market slightly decreased to USD 4364 million in 2015 which was USD 4367 million in the previous year. Market of United Kingdom as the 3rd largest exporter showed a tremendous growth (21 percent). In 2015, export to all other markets listed in tops ten except Belgium and Netherlands increased in export volume.

Figure 8-B: Top 10 Ready-made garments (RMG) importers of China

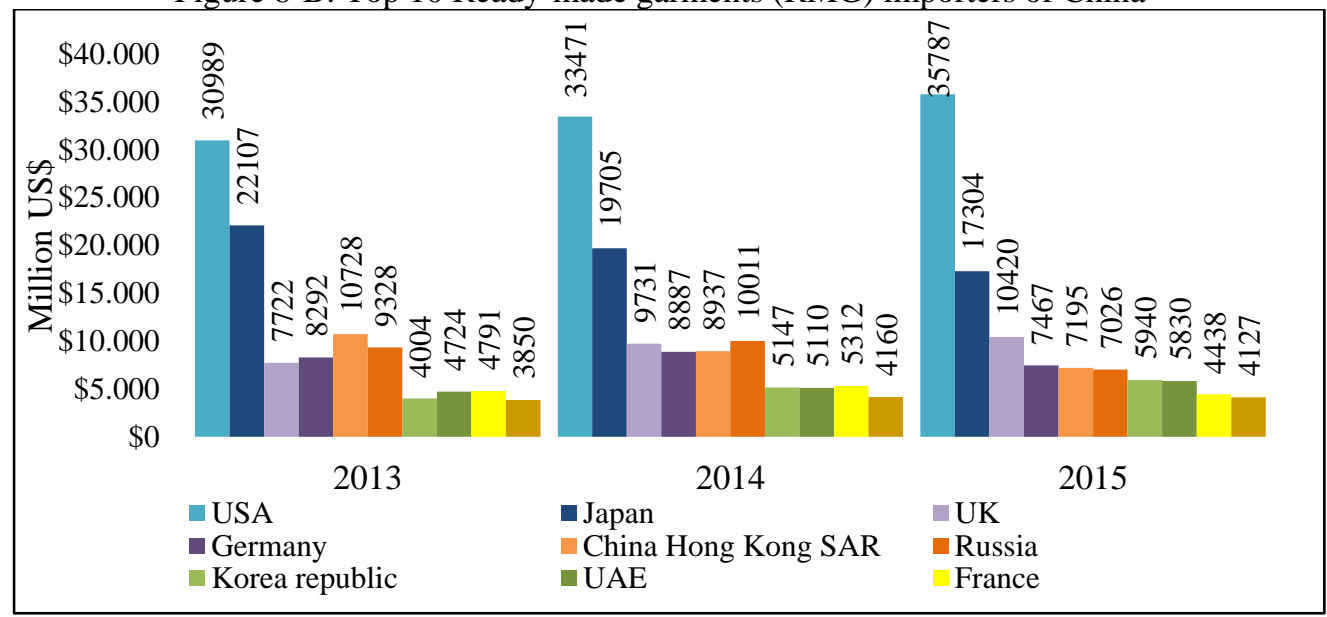

Source: UNCTAD Statistics data center.

China has become a major competitor of Bangladesh since its accession to the WTO. Still, it has been occupying the top position in the global apparel market. Despite the decline of annual growth, China increased its market share in the USA by USD 33471 million in 2014 to USD 35787 million in 2015. Other major importers of China are Japan, UK, Germany, China Hong Kong SAR, Russia, Korea Republic, UAE and France. Notably, six of the top ten importers of China imported less in 2015 than 2014. The countries imported less are Japan, Germany, Hong-Kong SAR, Russia, and France. During this period Bangladesh's share increased from USD 1560 (2014) to USD 1635 (2015) in France and USD 592 (2014) to USD 681 (2015) in Japan (Figure 8-A). 


\section{World's top 10 RMG importer's import (\%) from Bangladesh and China}

Figure 9: Export share in top 10 Ready-made Garments (RMG) importers of world in 2015

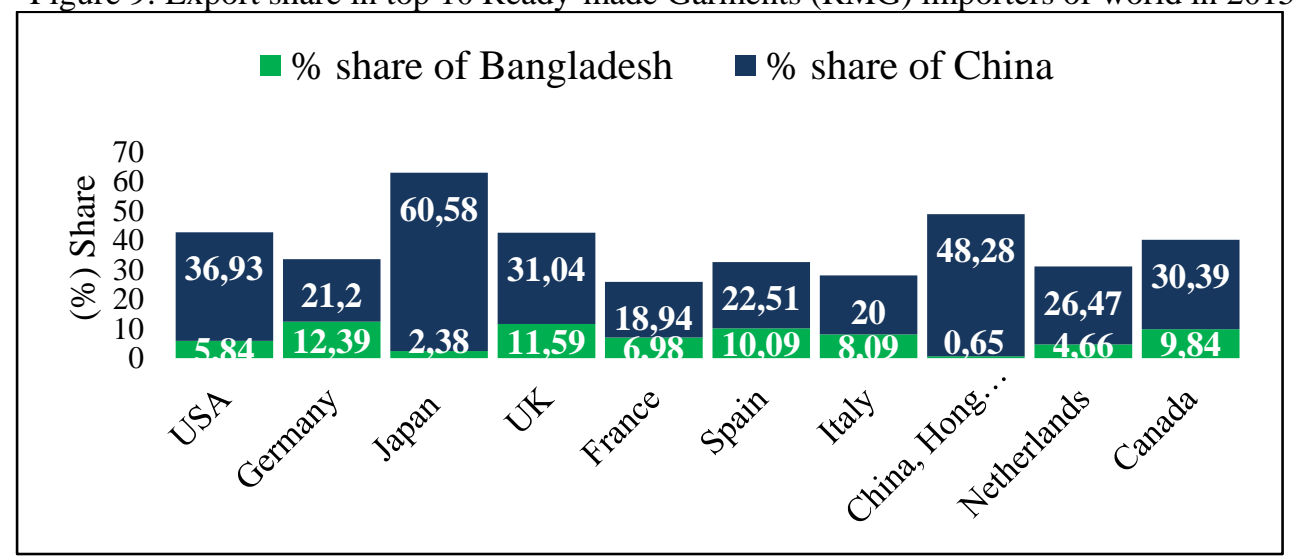

Source: Author's calculation based on Bangladesh and China's export earnings as of BGMEA trade database and UNCTAD statistics respectively.

USA the largest apparel market in world imported 5.84 percent from Bangladesh and 36.93 percent from China (Figure 9). Germany is the second largest importer of Bangladesh and fourth largest for China that imported 21.2 percent from China and 12.39 percent from Bangladesh in 2015. Japan being second largest importer of China imported 60.58 percent of its clothing items from China and Bangladesh has a very negligible share of (2.38 percent). China has the dominance over other markets too and the reason is simply the big size of its clothing industry, demand capacity with some other facilities such as price, lead time, etc.

\section{EU and USA market}

Figure 10-A: EU (28) and USA market for Bangladesh for both Knit and Woven items

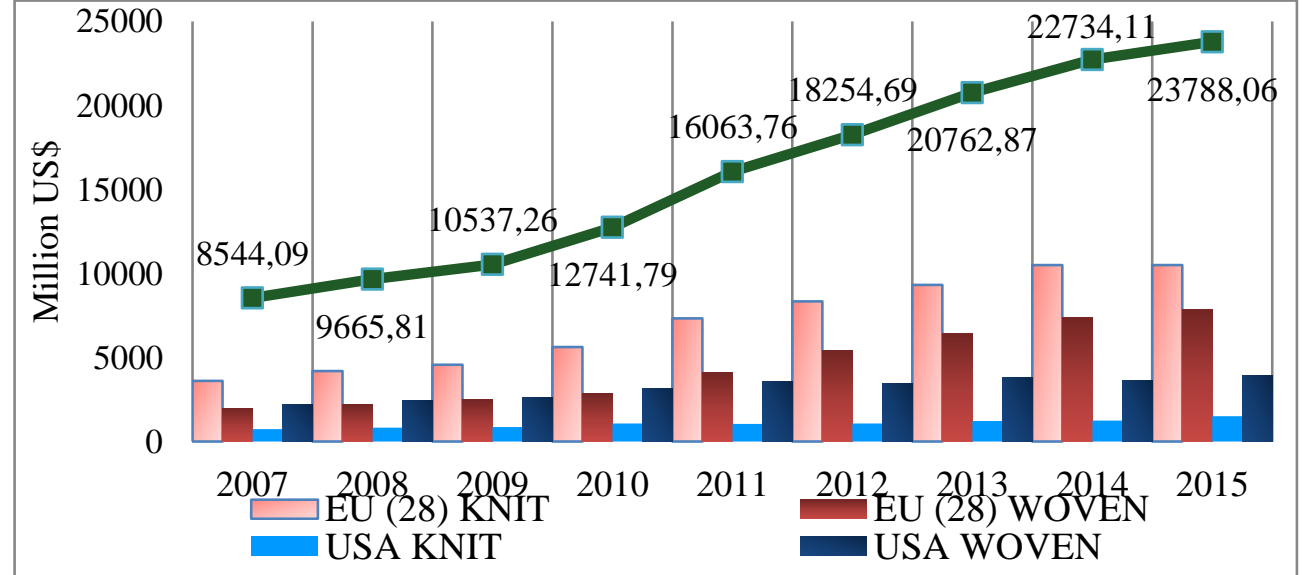

Source: International Trade Center (ITC). Product group 61 in Harmonized System (HS code) represents Knit items and 62 represent Woven clothing items. 
Bangladesh has high demand for the ready-made garment (RMG) exports in European Union. After the changes made on 18th November 2010 by the European Commission (EC) in the rules of origin (RoO) system that came into force on 1st January 2011, the export growth increased significantly to 15.06 per cent (2011-2015). On the contrary, the export growth of China in EU market didn't change notably during 2011-2015 rather decreased slightly ( -0.47 per cent). The main RMG export item of Bangladesh to the USA is woven garments. Export of woven items accounted for US\$ 3945 million in 2015 performing a tremendous growth from US\$ 2206 million in 2007 (Figure 10-A). From figure it is also apparent that woven items dominate as the most earning product for US market where Knit items lead the top position in case of China apparel export to USA. Knitwear did not play a prominent role in the export of RMG products from Bangladesh to the USA; but recent scenario has been changed in a small extent.

Figure 10-B: EU (28) and USA market for China for both Knit and Woven items

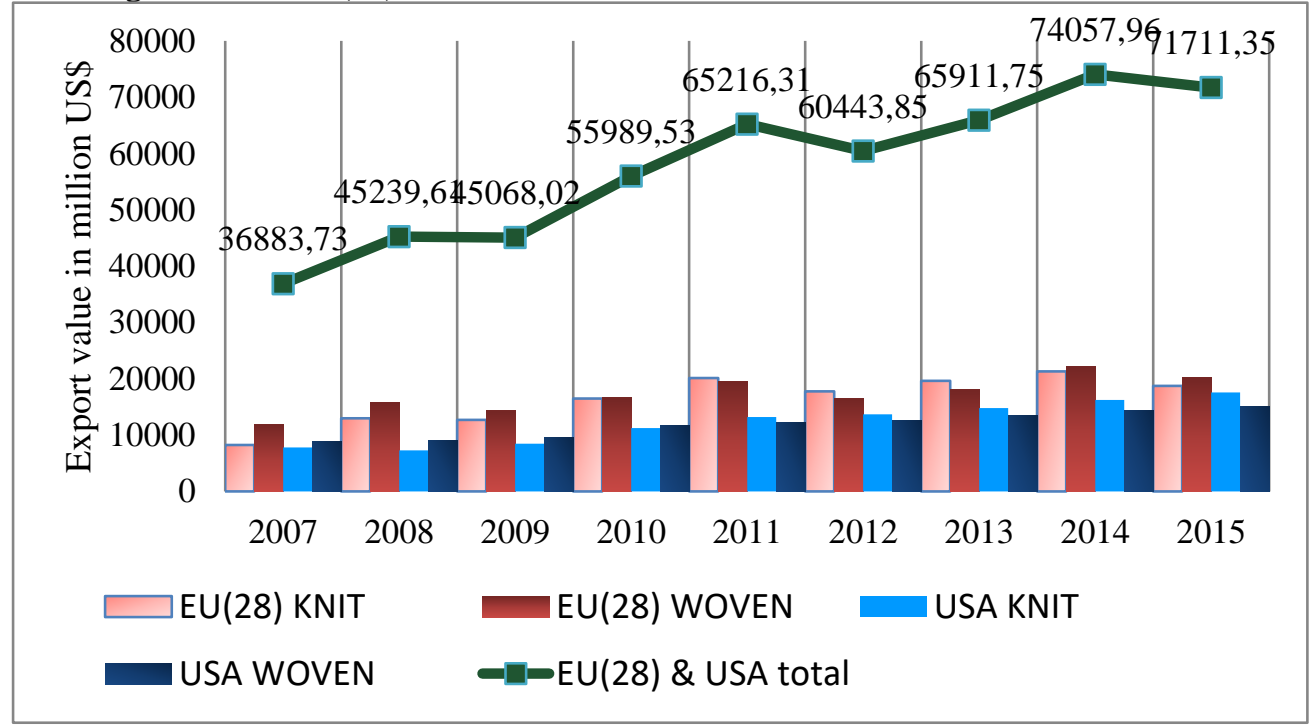

Source: International Trade Center (ITC). Product group 61 in Harmonized System (HS code) represents Knit items and 62 represent Woven clothing items.

Garment exports to USA, the largest apparel market for China after EU, accelerated US\$ 17580 million for Knit and US\$ 15141 million for woven in 2015. The earnings were US\$ 16236 million and US\$ 14304 million for knit and woven respectively in 2014 (Figure 10-B). In spite of increased export earnings from USA, the total export earnings from EU (28) and US market became less due to declined export earnings from EU (28). The export fell in 2015 although successive growth of preceding 3 years. Knit export accounted for US\$ 18742 million and woven export accounted 
for US\$ 20249 million which was US\$ 21317 million \& US\$ 22201 million for knit and woven respectively in 2014. Several factors are accelerating the growth of RMG sourcing from Bangladesh. The shortage of labour in coastal areas of China, increased wage, growing of more value added industries, shifting of workers for better jobs are some external factors mentioned in the McKinsey report. In addition, price attractiveness, the sufficiency of capacity to meet the high volume supply, favorable capability are numbered as the key strengths of Bangladesh to be the next choice of sourcing by the CPO's.

\section{Market diversification}

Figure 11: No of export markets for Knit and Woven items

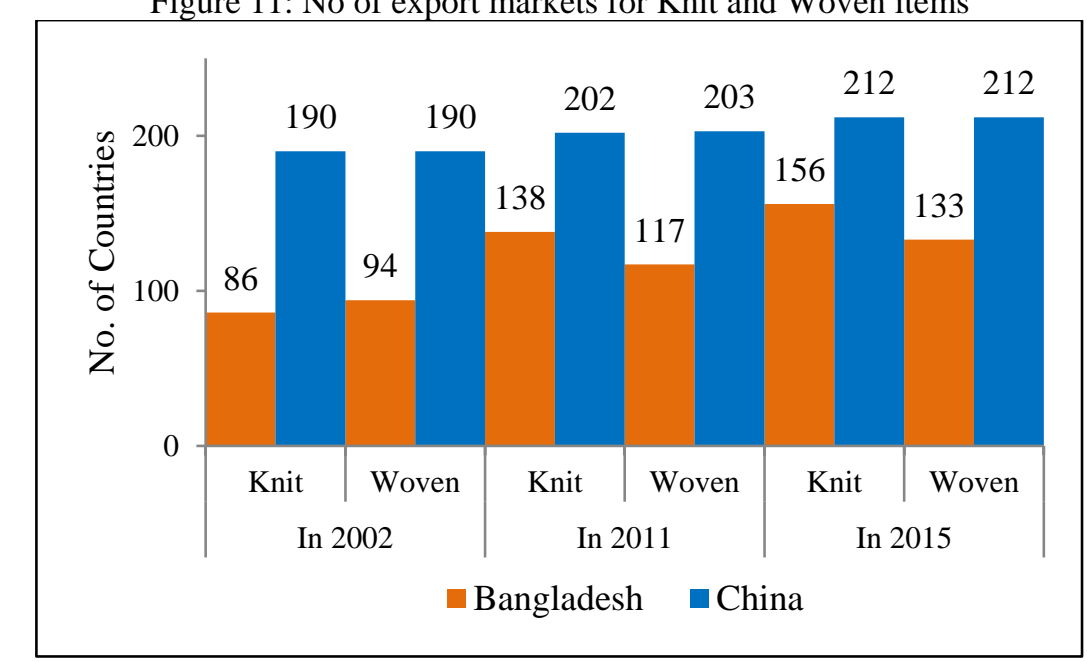

Source: Export Promotion Bureau (EPB) and International Trade Center (ITC).

As showed in figure 11, in 2002 Bangladesh's RMG items were exported to only 86 (knit) \& 94 (woven) destinations, whereas the number increased up to $138 \& 117$ for knit and woven respectively. In 2015 destinations further increased to $156 \& 133$ indicating development of newer 70 (knit) \& 39 (woven) markets. However, the rate of market exploration is higher for knitwear items compared to woven items.

In last decade, the number of destinations for apparel export of both Bangladesh and China increased where the improvement was noteworthy in case of Bangladesh. China's export destination for RMG products found additional 22 markets for both knit and woven items from 2002 to 2015. Still Bangladesh is too far away from China in terms of export destination which makes the big difference for higher export earnings. 


\section{Wage differences between Bangladesh and China}

Figure 12: Ready-made Garments worker wage in 2015

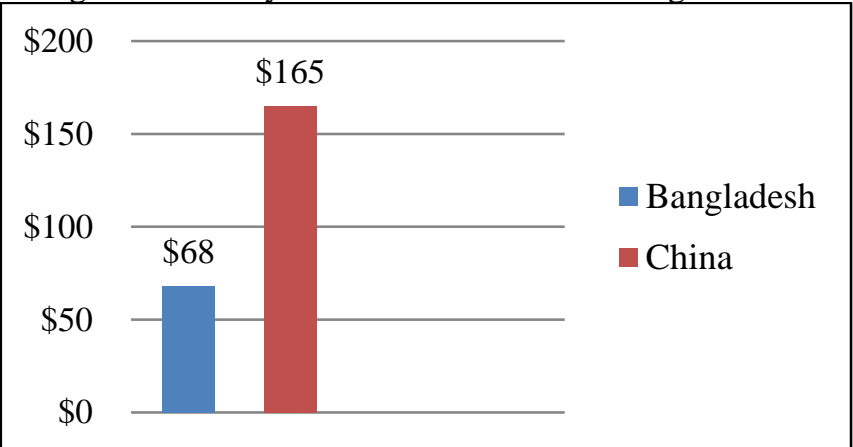

Source: ILO (Minimum wages in the global garment industry: Update for 2015)

Figure 13 provides a simple scenario of minimum wages in RMG sector in Bangladesh and China as ILO, 2015. In Bangladesh, Monthly minimum wage is US\$ 68 which was adopted in late 2013 aftermath of incessant labor unrest and lay-up of the workers. Monthly minimum wage in China is USD 165 which was adopted in May, 2013. Still, Bangladeshi worker's minimum wage is very cheaper compared to the other emerging garment producing countries as well as China.

\section{Export scenario in 2016}

The following chart shows the export scenario between Bangladesh and China with monthly export data in 2016

Table 1: Export scenario in 2016

\begin{tabular}{|c|c|c|c|c|c|c|}
\hline \multirow{2}{*}{} & \multicolumn{2}{|c|}{2015} & \multicolumn{2}{c|}{2016} & \multicolumn{2}{c|}{ Growth \% } \\
\cline { 2 - 7 } & China & Bangladesh & China & Bangladesh & China & Bangladesh \\
\hline December & 17098 & 2673 & 14273 & 2578 & -16.52 & -3.55 \\
\hline November & 13308 & 2224 & 12526 & 2310 & -5.88 & +3.87 \\
\hline October & 14445 & 1799 & 12839 & 2156 & -11.12 & +19.84 \\
\hline September & 17206 & 1954 & 15045 & 1822 & -12.56 & -6.76 \\
\hline August & 19083 & 2270 & 17686 & 2726 & -7.32 & +20.09 \\
\hline July & 17739 & 2215 & 16070 & 2118 & -9.41 & -4.38 \\
\hline June & 15881 & 2567 & 14889 & 3011 & -6.25 & +17.30 \\
\hline May & 13347 & 2359 & 13311 & 2447 & -0.27 & +3.73 \\
\hline April & 10456 & 1939 & 11195 & 2197 & +7.07 & +13.31 \\
\hline March & 6689 & 2075 & 8929 & 2312 & +33.49 & +11.42 \\
\hline February & 13279 & 2107 & 9575 & 2366 & -27.89 & +12.29 \\
\hline January & 15825 & 2420 & 14681 & 2626 & -7.23 & +8.51 \\
\hline Total & 174280 & 26602 & 157819 & 28669 & -9.45 & +7.77 \\
\hline
\end{tabular}

Source: BGMEA trade database (2016) and China Customs Statistics (2016). 
According to statistics from Chinese customs, the total export value of garments reached USD 157.8 billion in 2016. The growth rate of garment exports dropped to -9.45 percent. Bangladesh continued to sustain its positive growth rate in 2016 like previous years ( 7.77 percent). The export value reached to USD 28.67 billion (Table 1).

\section{Challenges of Bangladesh RMG sector}

Although the epic growth of RMG industry of Bangladesh, challenges are still there. However, challenges can become opportunities if they are addressed with higher concern from government and policy makers. Limitation lies in every vital stages of this industry. Some major limitations are discussed in this section.

Low prize of apparel products is one of the reason of sourcing from Bangladesh. It is often seen that RMG suppliers competes with each other to decrease the prize with a view to grab the order which eventually impacts on lower export income. Due to the homogeneity of garment industry products, competition among the suppliers are intense.

Another limitation is, still the textile industries of Bangladesh are not capable of producing high standard fabrics. Shortage of capital necessary to develop local sources for quality fabrics/yarn is a major weakness. The local textile can fulfill only 20 percent of domestic demand for woven fabrics. However, there is ample scope of textile industry to grow as it has a big domestic market for fabrics.

Unlike past Bangladesh government, employers and the owners of garments sector are giving priority to workplace safety, compliance-related issues and non-hazardous working conditions to prevent accidents. But the crises similar to Rana plaza and Tazrin Fashions can change the whole scenario of this rising sector if happens again. These would adversely affect the growth of RMG sector and can lead to a downward slope of Country's export value to world.

Several authors have analyzed aspects of the garment industry in Bangladesh. Of the various aspects of the industry, the problems and the working conditions of workers have received the greatest attention. In previous decades, this industry relied on low wages and minimum standards in working conditions, however low labour costs is not the prime driver of the sourcing decisions. In recent years customers are increasingly prioritizing productivity and reliability of supply. Hence they are also emphasizing to minimize reputational risks of poor working conditions.

The first victim of political violence is the garment sector as the exporters face challenges in production, marketing, distribution of raw materials and shipment. During the latest spell of shutdown, almost all garment factories suffered shipment hassle. Besides, poor road 
communication and a messy traffic system have made the sector vulnerable. The goods laden vehicles have to stand for hours in the traffic jam on the way to sea-port from the center of country. Many garment exporters complained that they cannot meet the strict lead-time set by the international buyers for delayed shipment in Chittagong port due to poor road condition. Moreover, the centralization of garment industries in the middle of the country made this situation more critical. So, political stabilization is the utmost need for garment sector.

Because of shortage of power and gas, the supply is not continuous which lead the industries to use generators for uninterrupted production, resulting in the increasing cost of productions. Many composite garment units are failing to start production only for the lack of gas connections in the factories.

In garments sector, very few workers get training before joining in their services. The training system is still very poor. For achieving higher prize with maximum quality of product, the skilled man-power should be one of the major concern for upcoming future of RMG. In this context, Government of Bangladesh has taken an initiative to increase skilled manpower mainly in garments sector. The program so called SEIP (Skill for Employment Investment Program).

Currently, Bangladesh do not enjoys the zero-duty benefits under the Generalized System of Preferences (GSP) from USA because of the massive collapse of "Rana Plaza" in 2013. Bangladesh supplied $6.57 \%$ of the readymade garments (RMG) in the US market last year. In the first 7 months of 2017 , it decreased to $6.41 \%$. But the competition has increased in Vietnam and India market. However it is expected that there will be no major fall.

Some other major limitation of Bangladesh in RMG industry is high dependency in imported raw materials, higher interest of bank loan, poor logistics and shipping facilities, rely upon foreign engineering services for maintenance of machine and utilities service etc.

\section{Conclusion}

The entrepreneurs of Bangladesh can demonstrate a remarkable ability to take the advantages of business opportunities that will emerge in future. Since the beginning, the industry has continued its growth and the export income are expected to become double in next five years. For Bangladeshi garment workers, wages have remained lower than other countries. The country also benefits from a large labor force and the garments industry is also growing up with this potential which offers capacity in size of an order. Also, weak domestic consumption, shortage of orders, increasing costs of electricity, and environmental controls have left Chinese textile companies striving to cope with international competition. To 
attain a strong position in world apparel market, Bangladesh should differentiate their products, take advantage of the free trade, zero tariff scheme agreement and integrate the industrial chain vertically and horizontally to make the pipeline more effective and hence enjoy cost savings. In light of the changes in market and fashion trends, Bangladesh should pay more attention to non-cost factors such as one-package buying, the application of Information and Communications Technology (ICT) in design and pattern making, speeding up the supply of samples, providing a variety of products and services, and enhance credit. The ongoing rise in Chinese wage and currency has made Bangladesh a favorable investment destination for largest clothing exporters of the world. Supply capacity to produce cost effective but quality RMG products with over 4500 factories, Bangladesh is clearly ahead than other suppliers in this respect where Indonesia has about 2450 factories, Vietnam 2000 and Cambodia 260 factories (BKMEA). Favorable trade agreements: EU-GSP everything but arms rules on duty-free imports of garments from Bangladesh has made sourcing from Bangladesh more attractive. Another key prospect for growth of Bangladesh's garment industry involved with the size of the global apparel market, which is following an augmentative path. Therefore, undoubtedly, there is a great opportunity in front to further penetrate the global apparel market and boost export earnings of Bangladesh. Proper planning should implement to boost up the RMG export. There should be separate garments industrial zone to simplify the transportation though shipments without barriers. Bangladesh has huge potentials if opportunities could be grabbed and used in a timely manner.

\section{References:}

1. Adnan, A., ATM., Rakib, A. and Rahman, M., (2015), "Export trend of Bangladesh: the dominance of ready-made garments industry," Research Journal of Economics, Business and ICT, Vol.10, Issue 1, pp. 25-31

2. Asgari, B. and Houqe, M.A. (2013), "Analyzing and modeling of supply chain performance in Bangladesh Ready Made Garments," Ritsumeikan Journal of Asia Pacific Studies, Vol.32, pp. 57-58.

3. Bangladesh economic review (2016), "Chapter-2: GDP, Savings, and Investment," Finance Division, Ministry of Finance, Government of the People's Republic of Bangladesh, pp. 1(1)

4. Berg, A., Hedrich, S., Kempf, S. and Tochtermann, T. (2011), "Bangladesh's ready-made garments landscape: The challenge of growth," McKinsey \& Company, pp. 3-6.

5. BGMEA Trade database, available at: http://www.bgmea.com.bd/home/pages/TradeInformation 
6. BKMEA Trade Data, available at:__http://www.bkmea.com/factsfigures.html

7. China Customs Statistics (2016), available at: http://info.hktdc.com/hktdc_offices/mi/ccs/index_static_type/GarmentsExport.htm

8. China National Garment Association, "China, the garment king: a portrait," Available

at: http://www.cnga.org.cn/engl/News/View.asp?NewsID=42568

9. Export Promotion Bureau (EPB), Statistic data, available at: http://epb.portal.gov.bd/site/files/9efa4995-2501-4c9e-8ca6-8b8f7208c3a0/Statistic

10. Fair Wear Foundation (2015), “China country study 2015,” pp. 13

11. Hasan, J. (2013), “The Competitiveness of Ready Made Garments Industry of Bangladesh in Post MFA Era: How Does the Industry Behave to Face the Competitive Challenge?," British Journal of Economics, Management \& Trade 3(3): 296-306.

12. Hossen, M.A. (2014), "Globalization and its impacts on Garments Sector in Bangladesh," Journal of Economics and Sustainable Development, Vol.5, No.24, pp. 80-85.

13. Hussain, Z. (2013), "Bangladesh: The Next China?," End Poverty in South Asia blog, South Asia Region of the World Bank group, available at: http://blogs.worldbank.org/endpovertyinsouthasia/bangladesh-nextchina

14. International Labour Organization, (2015), "Labour standards in global supply chains: A program of action for Asia and the garment sector," Research Note (December 2015), pp. 4-6.

15. International Trade Statistical Review (2016), "Merchandise trade," pp. 33.

16. International Trade Statistics (2006-2015), World Trade Organization, available at: https://www.wto.org/english/res_e/statis_e/its_e.htm

17. Mallon, G. and Whalley, J. (2004), "China's Post-Accession WTO Stance," Working paper (10649), National Bureau of Economic Research, Cambridge, August 2004.

18. Martin, W. (2009), "China's textile and clothing trade and global adjustment," Garnaut et al. (Ed.), China's New Place in a World in Crisis, ANU E Press, The Australian National University, pp. 304311.

19. Nuruzzaman, M. and Haque, A. (2009), "Lead time management in the garment sector of Bangladesh: an avenue for survival and growth," European Journal of Scientific Research 33(4): pp. 617-629.

20. Qiu, L. (2005), “China's Textile and Clothing Industry," Unpublished manuscript, Hong Kong University of Science and Technology, pp. $1-3$. 
21. Rahman, M.H., and Siddiqui, S.A. (2015), "RMG: Prospect of Contribution in Economy of Bangladesh," International Journal of Scientific and Research Publications, Vol.5, pp. 1-3.

22. The Financial Express (2017), "Govt. Seeks to raise investment to $32 \mathrm{pc}$ in next two years," 18 January, pp. 8.

23. Uddin, M.M. (2014), "How Bangladeshi Ready Made Garments Industry can be competitive in the global Market," Theseus. fi, pp. 54, available at: http://www.theseus.fi/handle/10024/80218?show=full

24. UNCTAD Statistics data center. Available at: http://unctadstat.unctad.org/wds/ReportFolders/reportFolders.aspx?sCS_ChosenLa $\mathrm{ng}=\mathrm{en}$

25. Wenqian, Z. (2016), "China's textile exports declined in 2015," China Daily, 14 January, available at: http://www.chinadaily.com.cn/bizchina/2016-01/14/content_23088319.htm

26. World Bank (2005), "Growth and export competitiveness," Bangladesh- Growth and Export Competitiveness, Chapter 1, Vol.1, pp. 3-6.

27. World Integrated Trade Solution (WITS), "China Trade Summary 2015 Data," available at: http://wits.worldbank.org/CountryProfile/en/Country/CHN/Year/2015/Summary

28. World Trade Statistical Review (2016), World Trade Organization, available

at: https://www.wto.org/english/res_e/statis_e/wts2016_e/wts16_toc_e.htm

29. Xiang, L. and Zhenzhen, X. (2010), "Garment Industry Analysis in China," Electronic publications from Karlstad University, pp. 53.

30. Yunus, M. and Yamagata, T. (2012), "The Garment Industry in Bangladesh," In: Fukunishi, T., Ed., Dynamics of the Garment Industry in Low-Income Countries: Experience of Asia and Africa, Interim Report, ChousakenKyu, Huokokusho, IDE-JETRO, Chapter 6.

31. Zhang, M., Kong, X.X. and Ramu, S.C. (2015), "The transformation of the clothing Industry in China," Economic Research Institute for ASEAN and East Asia, pp. 30-31. 